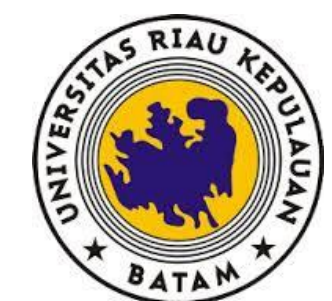

\title{
HUBUNGAN ANTARA KONSEP DIRI DENGAN PRESTASI BELAJAR
} SISWA

(THE RELATIONSHIP BETWEEN SELF CONCEPT AND STUDENT ACHIEVEMENT)

\section{Sri Wahyuni Adiningtiyas*, Maria Fresa Ompusunggu}

* Division of Counseling and Guidance, University, of Riau Kepulauan, Batam

\begin{abstract}
ABSTRAK
Konsep diri merupakan keseluruhan pandangan tentang diri sendiri, dengan kata lain konsep diri juga merupakan potret tentang bagaimana seseorang melihat, menilai, serta menyikapi diri. Konsep diri berkembang pada masa remaja, yakni rentangan 13-17 tahun. Konsep diri penting sekali diperhatikan, sebab konsep diri merupakan penentu tingkah laku seseorang dan merupakan pandangan terhadap diri sendiri yang merupakan dasar bagi semua tingkah laku. Bila individu mempunyai konsep diri yang rendah atau negative, individu akan menjadi kurang percaya diri, mudah putus asadan kurang berorientasi pada prestasi, sehingga akan mempengaruhi prestasi akademiknya di sekolah.
\end{abstract}

Kata Kunci: Konsep Diri, Prestasi Belajar

\section{ABSTRACT}

The concept of self is the whole view of self, in other words self concept is also a portrait of how one sees, assesses, and responds to self. Self concept develops in adolescence, the range of 13-17 years. Self concept is important to note, because self concept is a determinant of one's behavior and view of oneself that is the basis fo all behavior. When the individual has a low or negative self concept, the individual will become less confident, easily discouraged, and less achievement-oriented, thus affecting his academicachievement in school.

Keywords:self concept, student achievement

\section{PENDAHULUAN}

Pendidikan merupakan hal yang penting bagi kemajuan dan kelangsungan hidup individu. Individu memperoleh informasi dan pengetahuan yang dapat dipergunakan untuk mengembangkan diri berdasarkan kemampuan dan kesempatan yang ada. Tujuan pendidikan yaitu untuk meningkatkan kecerdasan, pengetahuan, kepribadian, akhlak mulia, keterampilan untuk hidup mandiri serta mengikuti pendidikan lebih lanjut. Pendidikan merupakan peran sentral dalam upaya mengembangkan sumber daya manusia.

Pendidikan di Indonesia dikembangkan berdasarkan pada Undang-undang Sistem Pendidikan Nasional (UUSPN No.20 Th.2003), yang mempunyai tujuan sebagai berikut :

\footnotetext{
"Pendidikan nasional berfungsi mengembangkan dan membentuk watak serta peradaban bangsa yang bermartabat dalam rangka mencerdaskan kehidupan bangsa, bertujuan untuk berkembangnya potensi peserta didik agar menjadi manusia yang beriman dan bertakwa kepada Tuhan Yang Maha Esa, berakhlak mulia, sehat, berilmu, cakap, kreatif, mandiri, dan menjadi warga negara yang demokratis serta bertanggung jawab (UUSPN No.20 Th 2003 Bab II Pasal 3)."
}

Prestasi belajar adalah hasil yang dicapai seseorang dalam pengusasaan pengetahuan dan keterampilan yang dikembangkan dalam pelajaran, lazimnya ditunjukkan dengan tes angka nilai yang diberikan oleh guru (Asmara, 2009). Prestasi 
Sri Wahyuni Adiningtyas dan Maria Fresa Ompusunggu / Jurnal Kopasta 5 (1), (2018) 23 - 31

belajar adalah keberhasilan peserta didik dalam menguasai materi yang telah diajarkan sehingga peserta didik dapat mencapai tujuan belajar yang telah ditetapkan. Informasi tentang prestasi belajar peserta didik dapat diperoleh melalui nilai rata-rata raport atau indeks prestasi setelah melaksanakan proses belajar mengajar selama satu semester (Tu'u, 2004).

Dalam proses interaksi ini individu tumbuh dan mulai belajar mengidentifikasi dirinya sendiri yaitu individu mulai membangun konsep diri yaitu sebuah sikap pandang terhadap dirinya sendiri dan sebagai penentu tingkah laku (Hurlock, 2001). Dari konsep diri inilah kemudian, memunculkan manifestasi perilaku individu yang berbeda pula, pola dalam konsep diri individu yang positif akan memiliki prodi posisi pada pengembangan kualitas kediriannya salah satunya dengan meningkatkan prestasi belajarnya, dengan peningkatan prestasi belajar bagi remaja merupakan pembuktian bahwa orang lain tidak salah menerima dirinya. Sebaliknya, pola dalam konsep diri yang negatif, cenderung menempatkan individu pada penolakan terhadap lingkungan akibat adanya perasaaan yang buruk. Ini sejalan dengan derajat konsep diri bahwa individu yang memiliki konsep diri yang positif, akan mengembangkan sifat-sifat percaya diri, harga diri dan kemampuan untuk melihat dirinya secara realistis, dapat menilai hubungan orang lain secara tepat sehingga menumbuhkan penyesuaian pribadi dan sosial yang baik hal yang berkebalikan pada individu yang memiliki konsep diri negatif, akan mengembangkan perasaan tidak mampu, rendah diri, ragu dan kurang percaya diri sehingga menimbulkan penyesuaian pribadi dan sosial yang buruk (Hurlock, 2001).

Eksistensi individu dalam lingkungannya disini tidak dapat kita teliti dari pola kognitif dan eksternal semata, melainkan juga pada kepribadian individu yakni konsep diri. Individu yang memiliki konsep diri yang positif cenderung menginginkan kompetisi sebagai medium aktualisasi dirinya, Sebaliknya individu yang memiliki konsep diri yang negatif cenderung mengalah pada kompetisi di lingkungannya (Colhoun, 1990). Menurut Stuart dan Sundeen konsep diri merupakan semua ide, pikiran, kepercayaan dan pendirian yang diketahui individu tentang dirinya dan mempengaruhi individu dalam berhubungan dengan orang lain (Budi Anna, 1992). Hurlock menuliskan bahwa konsep diri sebenarnya ialah gambaran yang dimiliki orang tentang dirinya. Konsep diri ini merupakan gabungan dari keyakinan yang dimiliki tentang diri mereka sendiri, yang berkaitan dengan karakteristik fisik, psikologis, sosial dan emosional, aspirasi serta prestasi. Konsep seseorang mengenai siapa dirinya. Konsep ini merupakan bayangan cermin, yang ditentukan sebagian besar oleh peran dan hubungan dengan orang lain dan reaksi orang lain terhadapnya.

Lingkungan yang dianggap paling banyak menawarkan kompetisi pada remaja dan sangat prestisius adalah institusi pendidikan. Institusi ini merupakan arena dimana semua orang mudah dipaksa untuk berkompetisi. Dalam berkompetisi mereka dipaksa untuk mengungkapkan kemampuan pribadi mereka pada kontest-kontest di depan publik. Dengan penekanan berat pada kompetisi dan 
Sri Wahyuni Adiningtyas dan Maria Fresa Ompusunggu / Jurnal Kopasta 5 (1), (2018) 23 - 31

tekanan-tekanan yang diterapkan oleh guru-guru dan oleh kebanyakan orang tua kepada anak-anak untuk meraih keberhasilan, maka tidaklah mengherankan bila para remaja tadi menggunakan pencapaian akademis sebagai suatu indeks harga diri yang penting. Disini evaluasi-evaluasi dari orang lain (terlebih institusi resmi) menjadi evaluasi-evaluasi diri, sehingga seorang siswa yang berhasil merasa kompeten dan berarti, sedangkan seorang siswa yang mengalami kegagalan menjadi merasa tidak kompeten dan inferior (Muhibbin Syah, 2002)

Ketika beranjak pada lingkungan akademis, maka posisi orang tua sebagai pusat utama informasi diri, mulai tergantikan dengan hadirnya guru-guru dan kelompok teman-teman sebaya. Meskipun konsep diri individu telah terbentuk dan cenderung statis, tetapi masih rentan terhadap modifikasi. Informasiinformasi berupa evaluasi dan otoritas dari guru-guru "orang lain yang dihormati" selanjutnya menjadi memberikan informasi kepada konsep diri murid-murid mereka berupa penguatan yang positif, netral dan yang negatif, dan menciptakan sebuah etos di dalam hubungan tersebut yang mungkin meningkatkan atau menurunkan prestasi akademik (Muhibbin Syah, 2002).

Berdasarkan hasil wawancara dengan beberapa guru di sekolah bahwa peserta didik sangat sulit mencapai kriteria ketuntasan minimal (KKM) yang sudah ditentukan di sekolah dengan nilai 80,5 yang menjadi nilai rata-rata sekolah. Proses pembelajaran setiap peserta didik tidak dapat selalu berlangsung secara wajar, kadang peserta didik belajar secara lancar, kadang tidak. Di lain waktu, adakalanya dapat dengan cepat menangkap apa yang akan dipelajari, kadang terasa sulit. Begitu juga dalam hal semangat belajar, kadang individu begitu antusias dan semangat dalam belajar, namun kadang juga mengalami kesulitan dalam hal konsentrasi..

Berdasarkan latar belakang diatas, maka peneliti tertarik untuk melakukan penelitian yang berjudul "Hubungan antara Konsep Diri dengan Prestasi Belajar Siswa"

\section{Pembahasan}

\section{a. Prestasi Belajar}

\section{Pengertian Prestasi Belajar}

Menurut Muhibbin Syah (2008) Untuk mengetahui prestasi belajar siswa dapat dilakukan dengan cara memberi penilaian atau evaluasi yaitu untuk memeriksa kesesuaian anatara apa yang diharapkan dan apa yang tercapai, hasil penelitian tersebut dapat digunakan untuk memperbaiki dan mendekatkan tujuan yang diinginkan. Sudjanah (dalam Tu'u 2004) mengatakan bahwa diantara ketiga ranah ini, yakni kognitif, afektif, dan psikomotorik, maka ranah kognitiflah yang paling sering dinilai oleh para guru disekolah karena berkaitan dengan kemampuan para siswa dalam menguasai isi bahan pengajaran. Karena itu, unsur yang ada dalam prestasi siswa terdiri dari hasil belajar dan nilai siswa. Tu'u (2004) menyatakan bahwa prestasi belajar adalah penguasaan atau keterampilan yang dikembangkan oleh mata pelajaran, lazimnya dengan nilai test atau angka yang diberikan oleh guru. 
Sri Wahyuni Adiningtyas dan Maria Fresa Ompusunggu / Jurnal Kopasta 5 (1), (2018) 23 - 31

Istilah prestasi belajar dalam Kamus Umum Bahasa Indonesia disebutkan bahwa prestasi adalah hasil yang dicapai dari apa yang dikerjakan atau yang sudah diusahakan. Prestasi belajar dapat diartikan sebagi hal-hal yang telah dicapai seseorang. Untuk mengetahui apa yang telah dicapai tersebut dilakukan suatu test, dimana jenis test yang digunakan untuk memperoleh keterangan tentang hal tersebut adalah prestasi belajar.

\section{Aspek Prestasi Belajar}

Salah satu prinsip dasar yang harus senantiasa diperhatikan dan dipegang dalam rangka evaluasi hasil belajar adalah prinsip kebulatan, dengan prinsip evaluator dalam melaksanakan evaluasi hasil belajar dituntut untuk mengevaluasi secara menyeluruh terhadap peserta didik, baik dari segi pemahamannya terhadap materi atau bahan pelajaran yang telah diberikan (aspek kognitif), maupun dari segi penghayatan (aspek afektif), dan pengamalannya (aspek psikomotoik) http://astinaelf.blogspot.co.id/2015/06/taksonomi-bloom-ranah-kognitif-afektif.html unduh 14/05/2017 jam 09.08

Ketiga aspek atau ranah kejiwaan itu erat sekali dan bahkan tidak mungkin dapat dilepaskan dari kegiatan atau proses evaluasi hasil belajar. Benjamin S. Bloom dan kawan-kawannya itu berpendapat bahwa pengelompokkan tujuan pendidikan itu harus senantiasa mengacu kepada tiga jenis domain (daerah binaan atau ranah) yang melekat pada diri peserta didik, yaitu:

A. Ranah Kognitif

Tujuan kognitif atau Ranah kognitif adalah ranah yang mencakup kegiatan mental (otak). Menurut Bloom, segala upaya yang menyangkut aktifitas otak adalah termasuk dalam ranah kognitif. Dalam ranah kognitif itu terdapat enam jenjang proses berfikir, mulai dari jenjang terendah sampai jenjang yang tertinggi yang meliputi 6 tingkatan antara lain :

a. Pengetahuan (Knowledge) - C1

Pada level atau tingkatan terendah ini dimaksudkan sebagai kemampuan mengingat kembali materi yang telah dipelajari, misalnya: (a) pengetahuan tentang istilah; (b) pengetahuan tentang fakta khusus; (c) pengetahuan tentang konvensi; (d) pengetahuan tentang kecendrungan dan urutan; (e) pengetahuan tentangklasifikasi dan kategori; (f) pengetahuan tentang kriteria; dan (g) pengetahuan tentang metodologi. Contoh: menyatakan kebijakan.

b. Pemahaman (Comprehension) - $\mathrm{C} 2$

Pada level atau tingkatan kedua ini, pemahaman diartikan sebagai kemampuan memahami materi tertentu, dapat dalam bentuk: (a) translasi (mengubah dari satu bentuk ke bentuk lain); (b) interpretasi (menjelaskan atau merangkum materi); (c) ekstrapolasi (memperpanjang/memperluas arti/memaknai data). Contoh : Menuliskan kembali atau merangkum materi pelajaran

c. Penerapan (Application) - C3 
Sri Wahyuni Adiningtyas dan Maria Fresa Ompusunggu / Jurnal Kopasta 5 (1), (2018) 23 - 31

Pada level atau tingkatan ketiga ini, aplikasi dimaksudkan sebagai kemampuan untuk menerapkan informasi dalam situasi nyata atau kemampuan menggunakan konsep dalam praktek atau situasi yang baru. Contoh: Menggunakan pedoman/ aturan dalam menghitung gaji pegawai.

d. Analisa (Analysis) - C4

Analisis adalah kategori atau tingkatan ke-4 dalam taksonomi Bloom tentang ranah (domain) kognitif. Analisis merupakan kemampuan menguraikan suatu materi menjadi bagian-bagiannya. Kemampuan menganalisis dapat berupa: (a) analisis elemen (mengidentifikasi bagian-bagian materi); (b) analisis hubungan (mengidentifikasi hubungan); (c) analisis pengorganisasian prinsip (mengidentifikasi pengorganisasian/organisasi). Contoh: Menganalisa penyebab meningkatnya Harga pokok penjualan dalam laporan keuangan dengan memisahkan komponen- komponennya.

e. Sintesis (Synthesis) - C5

Level kelima adalah sintesis yang dimaknai sebagai kemampuan untuk memproduksi. Tingkatan kognitif kelima ini dapat berupa: (a) memproduksi komunikasi yang unik; (b) memproduksi rencana atau kegiatan yang utuh; dan (c) menghasilkan/memproduksi seperangkat hubungan abstrak. Contoh: Menyusun kurikulum dengan mengintegrasikan pendapat dan materi dari beberapa sumber.

f. Evaluasi (Evaluation) - C6

Level ke-6 dari taksonomi Bloom pada ranah kognitif adalah evaluasi. Kemampuan melakukan evaluasi diartikan sebagai kemampuan menilai 'manfaat' suatu benda/hal untuk tujuan tertentu berdasarkan kriteria yang jelas. Paling tidak ada dua bentuk tingkat (level) evaluasi menurut Bloom, yaitu: (a) penilaian atau evaluasi berdasarkan bukti internal; dan (2) evaluasi berdasarkan bukti eksternal. Contoh: Membandingkan hasil ujian siswa dengan kunci jawaban.

\section{B. Ranah Afektif}

Ranah Afektif mencakup segala sesuatu yang terkait dengan emosi, misalnya perasaan, nilai, penghargaan, semangat,minat, motivasi, dan sikap. Lima kategori ranah ini diurutkan mulai dari perilaku yang sederhana hingga yang paling kompleks. a. Penerimaan (Receiving) - A1

Mengacu kepada kemampuan memperhatikan dan memberikan respon terhadap sitimulasi yang tepat. Penerimaan merupakan tingkat hasil belajar terendah dalam domain afektif. Dankemampuan untuk menunjukkan atensi dan penghargaan terhadap orang lain. Contoh: mendengar pendapat orang lain, mengingat nama seseorang.

b. Responsive (Responding) - A2

Satu tingkat di atas penerimaan. Dalam hal ini siswa menjadi terlibat secara afektif, menjadi peserta dan tertarik. Kemampuan berpartisipasi aktif dalam 
Sri Wahyuni Adiningtyas dan Maria Fresa Ompusunggu / Jurnal Kopasta 5 (1), (2018) 23 - 31

pembelajaran dan selalu termotivasi untuk segera bereaksi dan mengambil tindakan atas suatu kejadian. Contoh: berpartisipasi dalam diskusi kelas

c. Nilai yang dianut (Value) - A3

Mengacu kepada nilai atau pentingnya kita menterikatkan diri pada objek atau kejadian tertentu dengan reaksi-reaksi seperti menerima, menolak atau tidak menghiraukan. Tujuan-tujuan tersebut dapat diklasifikasikan menjadi "sikap dan opresiasi". Serta Kemampuan menunjukkan nilai yang dianut untuk membedakan mana yang baik dan kurang baik terhadap suatu kejadian/obyek, dan nilai tersebut diekspresikan dalam perilaku. Contoh: Mengusulkan kegiatanCorporate Social Responsibility sesuai dengan nilai yang berlaku dan komitmen perusahaan.

d. Organisasi (Organization) - A4

Mengacu kepada penyatuan nilai, sikap-sikap yang berbeda yang membuat lebih konsisten dapat menimbulkan konflik-konflik internal dan membentuk suatu sistem nilai internal, mencakup tingkah laku yang tercermin dalam suatu filsafat hidup. Dan Kemampuan membentuksystem nilai dan budaya organisasi dengan mengharmonisasikan perbedaan nilai. Contoh: Menyepakati dan mentaati etika profesi, mengakui perlunya keseimbangan antara kebebasan dan tanggung jawab.

e. Karakterisasi (characterization) - A5

Mengacu kepada karakter dan daya hidup sesorang. Nilai-nilai sangat berkembang nilai teratur sehingga tingkah laku menjadi lebih konsisten dan lebih mudah diperkirakan. Tujuan dalam kategori ini ada hubungannya dengan keteraturan pribadi, sosial dan emosi jiwa. DanKemampuan mengendalikan perilaku berdasarkan nilai yang dianut dan memperbaiki hubungan intrapersonal, interpersonal dan social. Contoh: Menunjukkan rasa percaya diri ketika bekerja sendiri, kooperatif dalam aktivitas kelompok

\section{Ranah Psikomotorik}

Ranah Psikomotorik meliputi gerakan dan koordinasi jasmani, keterampilan motorik dan kemampuan fisik. Ketrampilan ini dapat diasah jika sering melakukannya. Perkembangan tersebut dapat diukur sudut kecepatan, ketepatan, jarak, cara/teknik pelaksanaan. Ada tujuh kategori dalam ranah psikomotorik mulai dari tingkat yang sederhana hingga tingkat yang rumit.

a. Peniruan - P1

Terjadi ketika siswa mengamati suatu gerakan. Mulai memberi respons serupa dengan yang diamati. Mengurangi koordinasi dan kontrol otot-otot saraf. Peniruan ini pada umumnya dalam bentuk global dan tidak sempurna.

b. Manipulasi-P2

Menekankan perkembangan kemampuan mengikuti pengarahan, penampilan, gerakan-gerakan pilihan yang menetapkan suatu penampilan melalui latihan. Pada tingkat ini siswa menampilkan sesuatu menurut petunjuk-petunjuk tidak hanya meniru tingkah laku saja. 
c. Ketetapan $-\mathrm{P} 3$

Memerlukan kecermatan, proporsi dan kepastian yang lebih tinggi dalam penampilan. Respon-respon lebih terkoreksi dan kesalahan-kesalahan dibatasi sampai pada tingkat minimum.

d. Artikulasi - P4

Menekankan koordinasi suatu rangkaian gerakan dengan membuat urutan yang tepat dan mencapai yang diharapkan atau konsistensi internal di natara gerakan-gerakan yang berbeda.

e. Pengalamiahan - P5

Menurut tingkah laku yang ditampilkan dengan paling sedikit mengeluarkan energi fisik maupun psikis. Gerakannya dilakukan secara rutin. Pengalamiahan merupakan tingkat kemampuan tertinggi dalam domain psikomotorik.

\section{Faktor Yang Mempengaruhi Prestasi Belajar}

Menurut Merson U. Sangalang, faktor-faktor yang mempengaruhi prestasi yang dikutip oleh Kartini Kartono dalam Tu'us (2004) adalah sebagai berikut :

\section{Faktor Kecerdasan}

Dalam Macmilin Dictionary, Intellegence (kecerdasan) diberi arti sebagai ability to learn from experience, to solve problem rationally, and to modify behaviour with changes inenviroment, faculty of understending and reasoning. Rumusan tersebut menunjukan bahwa kecerdasan menyangkut kemampuan yang luas, tidak hanya kemampuan memahami, mengerti, memecahkan masalah, tetapi termasuk kemampuan mengatur perilaku berhadapan dengan lingkungan yang berubah dan kemampuan belajar dari pengalamannya. Tinggi rendahnya kecerdasan yang dimiliki seorang siswa sangat menentukan keberhasilannya mencapai prestasi belajar.

2. Faktor bakat

Bakat adalah kemampuan yang ada pada seseorang yang dibawanya sejak lahir, yang diterima sebagai warisan dari orang tua. Bakat dari tiap orang berbeda satu sama lain. Agar memperoleh prestasi yang tinggi sebaiknya diberikan kebebasan bagi setiap orang untuk belajar sesuai dengan bakat yang dimiliki.

3. Faktor minat dan perhatian

Minat dan perhatian mempunyai hubungan yang sangat erat. Seorang siswa yang memiliki minat pada suatu pelajaran biasanya cenderung untuk memperhatikannya dengan baik. Minat dan perhatian yang tinggi akan memberi dampak yang baik bagi prestasi belajar siswa.

4. Faktor konsep diri

Dalam belajar, faktor dikhususkan ke konsep diri, yaitu dengan adanya konsep diri yang tinggi. Konsep diri yang tinggi akan memudahkan siswa untuk terdorong belajar secara mandiri dan kreatif. Hal itu akan memperbesar usaha dan kegiatannya mencapai prestasi yang tinggi. 
5. Faktor cara belajar

Keberhasilan studi siswa dipengaruhi juga oleh belajar siswa. Cara belajar yang efisien memungkinkan mencapai prestasi lebih tinggi dibandingkan dengan cara belajar yang tidak efisien.

6. Faktor sekolah

Sekolah adalah lingkungan kedua yang berperan besar memberi pengaruh pada prestasi belajar siswa. Situasi yang kondusif, hubungan dan komunikasi perorang di sekolah berjalan baik,metode pembelajaran aktifinteraktif, sarana penunjang cukup memadai dan siswa tertib disiplin akan mendorong siswa saling berkompetisi dalam pembelajaran yang diharapkan hasil belajar yang diperoleh tinggi.

\section{Fungsi Prestasi Belajar}

Menurut Arifin (2011), prestasi belajar mempunyai beberapa fungsi sebagai berikut:

1) Sebagai indikator kualitas dan kuantitas pengetahuan yang telah dikuasai anak didik.

2) Sebagai lambang pemuasan hasrat ingin tahu.

3) Sebagai bahan informasi dalam inovasi pendidikan.

4) Sebagai indikator intern dan ekstern dari suatu institusi pendidikan.

5) Dapat dijadikan sebagai indikator terhadap daya serap anak didik.

5. Tujuan Prestasi Belajar

Menurut Arifin (2011), tujuan prestasi belajar adalah sebagai berikut:

1) Untuk mengetahui tingkat penguasaan siswa terhadap materi pelajaran yang telah disampaikan.

2) Untuk mengetahui kecapakan, motivasi, bakat, minat, dan konsep siswa terhadap program pembelajaran.

3) Untuk mengetahui tingkat kemajuan dan kesesuaian hasil belajar atau prestasi belajar siswa dengan standar kompetensi dasar yang telah ditetapkan.

4) Untuk mendiagnosis keunggulan dan kelemahan siswa dalam mengikuti kegiatan pembelajaran.

5) Untuk seleksi yaitu memilih dan menentukan siswa yang sesuai dengan jenis pendidikan tertentu.

6) Untuk menentukan kenaikan kelas.

7) Untuk menempatkan siswa sesuai dengan potensi yang dimilikinya

\section{Penutup}

Masalah konsep diri siswa menyebabkan rendahnya minat belajar. Ini terbukti masih banyak guru dalam proses belajar mengajar cenderung menghabiskan materi saja, tidak memberikan dorongan kepada para siswanya untuk giat belajar. Keberhasilan peserta didik dalam belajar bukan hanya ditentukan oleh kemampuan intelektual, tetapi juga oleh segi-segi afektif, terutama konsep diri. Konsep diri inilah 
yang akan menjadi motivasi bagi siswa untuk mencari jalannya sendiri dalam menempuh pendidikannya. Perbedaan konsep diri terdapat pada tiap individu, sebagaimana yang dikatakan oleh Hurlock bahwa konsep diri mempunyai peranan penting karena konsep diri akan menentukan apa yang diketahui dan diyakini seseorang tentang dirinya dan apa yang akan dilakukannya

\section{Kesimpulan}

Sekolah sebagai lembaga pendidikan formal memiliki tanggung jawab yang besar dalam mengembangkan semua potensi yang dimiliki siswa. Sekolah juga merupakan wahana pendidikan formal yang berperan dalam mengembangkan kualitas manusia Indonesia sejak dini, karena sekolah merupakan tempat dilaksanakannya kegiatan pendidikan, pembelajaran dan latihan. Generasi muda pada suatu negara pada dasarnya merupakan salah satu unsur pokok untuk keberlangsungan suatu negara. Kemajuan suatu negara akan sangat dipengaruhi oleh kualitas generasi muda pada negara tersebut. Siswa dalam mengembangkan kulaitas diri dalam hal prestasi belajar harus memiliki konsep diri yang positif sehingga proses pembelajaran berlangsung efektif.

\section{DAFTAR PUSTAKA}

Arifin. 2011. Penelitian Pendidikan. Bandung: Remaja Rosdakarya.

Asmara. 2009. Prestasi Belajar. Bandung: Remaja Rosdakarya.

Budi Anna. 1992. Konsep Diri. Jakarta: EGC.

Colhoun. 1990. Pschology of Adjustment Human Relationship (3th ed). New York: McGraw-Hill.

Hurlock, E.B. 2001. Psikologi Perkembangan: Suatu Pendekatan Sepanjang Rentang Kehidupan. Jakarta: Erlangga.

Muhibbin Syah. 2002. Psikologi Pendidikan dengan Pendekatan Baru. Bandung: Remaja Rosdakarya.

Tulus Tu'u. 2004. Peran Disiplin pada Perilaku dan Prestasi Siswa. Jakarta: Qrasindo. 